\title{
Preventive Effect of Traditional Korean Formulations on Intimal Thickening of Rat Carotid Artery Injured by Balloon Catheter
}

\author{
Seong Bin Kim, Keshav Raj Paudel ${ }^{1}$ and Dong Wook Kim ${ }^{1}$ * \\ Jeollanamdo Forest Resources Research Institute, Naju 520-833, Korea \\ ${ }^{1}$ Department of Oriental Medicine Resources, Mokpo National University, Muan 534-729, Korea
}

\begin{abstract}
The objective of this study was to examine the effect of 7 traditional Korean formulations (7TKFs) on intimal thickening of rat carotid artery injured by balloon catheter in vivo and on the proliferation of human smooth muscle cells (HASMCs) and secretion of matrix metalloproteinase-2 (MMP-2) in vitro. 7TKFs (400 mg/kg) were administered orally for 4 weeks from the day of balloon injury in the rats. HASMC proliferation was assessed by 3-(4,5-dimethylthiazol-2)-2,5diphenyltetrazolium bromide (MTT) assay while enzymatic action of MMP-2 was carried out by gelatin zymography. Among 7TKFs, Samhwang-sasim-tang (SST), Banha-sasim-tang (BST) and Kegi-honghwa-tang (KHT) significantly reduced the intimal thickening by suppressing HASMC proliferation and MMP-2 expression in both extracellular and intracellular levels. Thus, the results suggest that SST, BST and KHT can be considered as a therapeutic value in the prevention of atherosclerosis because restenosis after PTCA (percutaneous transluminal coronary angioplasty) is supposed to be 'accelerated atherosclerosis'.
\end{abstract}

Key words - PTCA, 7TKFs, Intimal thickening, HASMC

\section{Introduction}

Percutaneous transluminal coronary angioplasty (PTCA) is an important therapeutic option in the treatment of patients with coronary artery disease. However, a problem with this method remains the restenosis of the artery occurring within the first 6 months after the procedure (Topol et al., 1993). Although systemic pharmacological approaches to reduce restenosis have not been successful in clinical use, local treatment with drug-eluting stent (DES) demonstrated significant reduction in restenosis rate and the subsequent need for revascularization (Dobesh et al., 2004). Nevertheless, DES does not resolve all the problems arising from percutaneous coronary intervention (PCI) and may be associated with an increased risk for late stent thrombosis (Bavry et al., 2005; Nilsen et al., 2006). Mechanism of restenosis can be described as the complex involvement of several growth factors and cytokines that induce proliferation and migration of vascular smooth muscle cells (VSMCs) and degradation of extracellular matrix (ECM) by matrix metalloproteinases (MMPs) (Jackson

*Corresponding author. E-mail : dbkim@mokpo.ac.kr and Schwartz, 1992). During the early stages of arterial wall injury or atherosclerosis, VSMC may undergo transition from a contractile to a synthetic phenotype and begin proliferating in response to various growth factors. VSMCs, which accumulate within the intima, are derived from the proliferation of the intimal VSMCs and their migration from the media (Bendeck et al., 1994). Migration of VSMC may require the degradation or remodeling of ECM surrounding the cells (Matrisian et al., 1990; Sasaguri et al., 1994). For ECM degradation or remodeling, a number of in vivo and in vitro studies have been established to relate MMPs, specifically MMP-2 (72 kDa) and MMP-9 (92 kDa), proliferation and migration of VSMC into the intima (Newby and Zaltsman, 2000; Woessner, 1991). The main function of MMPs, known as matrixins, is degradation of the ECM and contributes to pathological conditions including rheumatoid arthritis, coronary artery disease and cancer (Hideaki and Frederick, 1999; Anitha and Tuszynski, 2001). Upon endothelial denudation, there is release of MMPs that disrupt the ECM thereby facilitating VSMCs to migrate from the medial layer of arterial wall into the intimal space and then intimal VSMCs undergo proliferation progressively resulting in neo-intima formation (Glass and Witztum, 2001). 
In this study, we have selected 7 traditional Korean formulations (7TKFs) which have been commonly prescribed in patients who have an oppressive feeling over the chest, insomnia and palpitations. An endeavor has been made to delineate the edifying effect of 7TKFs on proliferation and expression of MMP-2 in human smooth muscle cells (HASMC), which are the key steps in the progression of intimal thickening. The data likely to be generated by this paradigm might be helpful to investigate the claim on these formulations.

\section{Materials and Methods}

\section{Preparation of water extract of 7TKFs}

The herbal crude drugs were according to the standard as mentioned in Korean Pharmacopoeia and Korean Herbal Pharmacopoeia, which are the official compendia of standard. The voucher specimens were deposited at the laboratory of herbal medicine pharmacology, Mokpo National University. The composition of 7TKFs is as shown in Table $1.600 \mathrm{~g}$ of each indicated formulation was boiled in $2000 \mathrm{ml}$ of distilled water for $3 \mathrm{~h}$ and repeated for 3 times. Then, each extract, after filtration, was evaporated and freeze dried. The yield of each dried extract was about $20 \%$ of the starting material.

\section{Balloon endothelial denudation in rat carotid artery}

Male Wistar rats (13 weeks old), which were purchased from Central Laboratory Animal Inc., Seoul, were maintained under controlled environment with $12 \mathrm{~h}$ light-dark cycle, 100\% fresh hepa-filtered air, $23 \pm 1{ }^{\circ} \mathrm{C}$ temperature and $45 \pm 5 \%$ humidity in the Animal Research Center, Mokpo National University. Basal diet and sterilized water by ultraviolet were supplied without any restriction during the experiment. Balloon catheter denudation of the carotid artery was performed according to the method of Kim et al., 2002. Briefly, the right iliac artery of rats anaesthetized by pentobarbital $(50 \mathrm{mg} / \mathrm{kg}$, intraperitoneal injection) was cannulated with a balloon catheter (2F, Edwards Life sciences ${ }^{\mathrm{TM}}$, USA) and the balloon was inflated with saline $(0.02 \mathrm{ml})$ and rotated while pulling it back through the common carotid to denude the vessel of endothelium. All animal experiments were carried out in accordance with the Guidelines of the Animal Care and Use Committee of
Mokpo National University approved by the Korean Association of Laboratory Animal Care. Each formulation of 7TKFs was administered orally (400 mg/kg) using a gastric sonde for 4 weeks from the day of denudation. The control group was administered with distilled water.

\section{Carotid artery histological analyses}

After 4 weeks of denudation, the rats were anaesthetized with ether and perfused transcardially with saline and fixed in $10 \%$ buffered formaldehyde. The left carotid artery was removed, embedded in paraffin and microtomed in $7 \mu \mathrm{m}$ thick sections. The sections were deparaffinized in xylene, dehydrated in graded alcohol bath and stained with haematoxylin and eosin. The cross-sectional areas were examined by Axio Vert Rel. 4.2 image analysis program to measure luminal, medial and intimal areas. Later, I/M ratio [(intimal area) / (medial area) $]$ and the stenosis rate [(intimal area) $\times 100 /$ (intimal area + luminal area)] were calculated.

\section{Cell culture}

HASMC were purchased from Bio-Whittaker (San Diego, CA) and cultured in $10 \%$ fetal bovine serum (FBS). For all experiments, early passages of HASMCs were grown to 80 $90 \%$ confluence. In a typical experiment, the cells were starved in $0.4 \%$ FBS for $24 \mathrm{~h}$

\section{Proliferation assay}

HASMCs, seeded at a density of $1 \times 10^{4}$ cells/well, were starved for $24 \mathrm{~h}$. Next, they were treated with various concentrations of 7TKFs for $24 \mathrm{~h}$ in the presence of $10 \%$ FBS. Four hours after the addition of MTT $(0.1 \mathrm{mg} / \mathrm{ml})$, the resulting formazan crystals were solubilized in $100 \mu \mathrm{l}$ of dimethyl sulphoxide (DMSO) and absorbance was taken at $540 \mathrm{~nm}$.

\section{Gelatin zymography}

HASMCs were treated with $100 \mathrm{mg} / \mathrm{ml}$ of 7TKFs for $24 \mathrm{~h}$. The conditioned medium and cell lysate were collected and subjected to $10 \%$ sodium dodecyl sulfate polyacrylamide gel electrophoresis (SDS-PAGE) containing $0.1 \%$ gelatin as described by Yoon et al., 2010. 
Table 1. Composition of 7 traditional Korean formulations (7TKFs)

\begin{tabular}{|c|c|c|c|}
\hline No. & 7TKFs & Constituents & Ratio \\
\hline 1 & Samhwang-sasim-tang (SST) & $\begin{array}{l}\text { Scutellaria baicalensis } \\
\text { Coptis japonica } \\
\text { Rheum palmatum }\end{array}$ & $\begin{array}{l}\text { radix } 1 \\
\text { rhizome } 1 \\
\text { rhizome } 1\end{array}$ \\
\hline 2 & Banha-sasim-tang (BST) & $\begin{array}{l}\text { Pinellia ternate } \\
\text { Coptis japonica } \\
\text { Scutellaria baicalensis } \\
\text { Zingiber officinale } \\
\text { Panax ginseng } \\
\text { Glycyrrhiza glabra } \\
\text { Zizyphus jujuba }\end{array}$ & $\begin{array}{l}\text { tuber } 6 \\
\text { rhizome } 1 \\
\text { radix } 3 \\
\text { rhizome } 3 \\
\text { radix } 3 \\
\text { radix } 3 \\
\text { fructus } 3\end{array}$ \\
\hline 3 & Kegi-honghwa-tang (KHT) & $\begin{array}{l}\text { Cinnamomum cassia } \\
\text { Paeonia lactiflora } \\
\text { Glycyrrhiza glabra } \\
\text { Carthamus tinctorius } \\
\text { Zingiber officinale } \\
\text { Zizyphus jujuba }\end{array}$ & $\begin{array}{l}\text { ramulus } 1.5 \\
\text { radix } 1.5 \\
\text { radix } 1.5 \\
\text { flos } 1 \\
\text { rhizome } 1 \\
\text { fructus } 0.5\end{array}$ \\
\hline 4 & Kegi-bokryeung-hwan (KBH) & $\begin{array}{l}\text { Cinnamomum cassia } \\
\text { Poria cocos } \\
\text { Paeonia lactiflora } \\
\text { Paeonia suffruticosa } \\
\text { Prunus persica }\end{array}$ & $\begin{array}{c}\text { ramulus } 1 \\
\text { hoelen } 1 \\
\text { radix } 1 \\
\text { moutan cortex radicis } 1 \\
\text { semen } 1\end{array}$ \\
\hline 5 & Tae-siho-tang (TST) & $\begin{array}{l}\text { Bupleurum falcatum } \\
\text { Scutellaria baicalensis } \\
\text { Paeonia lactiflora } \\
\text { Pinellia ternate } \\
\text { Zingiber officinale } \\
\text { Zizyphus jujuba } \\
\text { Poncirus trifoliate } \\
\text { Rheum palmatum }\end{array}$ & $\begin{array}{l}\text { radix } 3 \\
\text { radix } 1.5 \\
\text { radix } 1.5 \\
\text { tuber } 3 \\
\text { rhizome } 2 \\
\text { fructus } 1.5 \\
\text { fructus } 1.5 \\
\text { rhizome } 1\end{array}$ \\
\hline 6 & Silso-san (SSS) & $\begin{array}{l}\text { Trogopterus xanthipes } \\
\text { Typha orientalis }\end{array}$ & $\begin{array}{c}\text { trogopterorum faeces } 1 \\
\text { typhae pollen } 1\end{array}$ \\
\hline 7 & Chilmul-kangha-tang (CKT) & $\begin{array}{l}\text { Angelica gigas } \\
\text { Rehmannia glutinosa } \\
\text { Paeonia lactiflora } \\
\text { Uncaria sinensis } \\
\text { Cnidium officinale } \\
\text { Astragalus membranaceus } \\
\text { Phellodendron amurense }\end{array}$ & $\begin{array}{c}\text { radix } 2 \\
\text { radix } 2 \\
\text { radix } 2 \\
\text { ramulus et uncus } 2 \\
\text { rhizome } 2 \\
\text { radix } 1.5 \\
\text { cortex } 1\end{array}$ \\
\hline
\end{tabular}

\section{Statistical analysis}

The results are shown as the means \pm standard deviation of three independent experiments. Statistical significance of the difference between the groups was determined by a student's $t$ test analysis of variation. Values of $p<0.05$ were considered significant.

\section{Results and Discussion}

\section{Effect of 7TKFs on intimal thickening}

Typical light micrographs of carotid arteries of control and 7 traditional Korean formulations (7TKFs) administered groups at 28 days after balloon injury are as shown in Fig. 1. Intimal hyperplasia formation was quantitatively recorded by a computerassisted morphometric analysis. There were no intimal lesions 

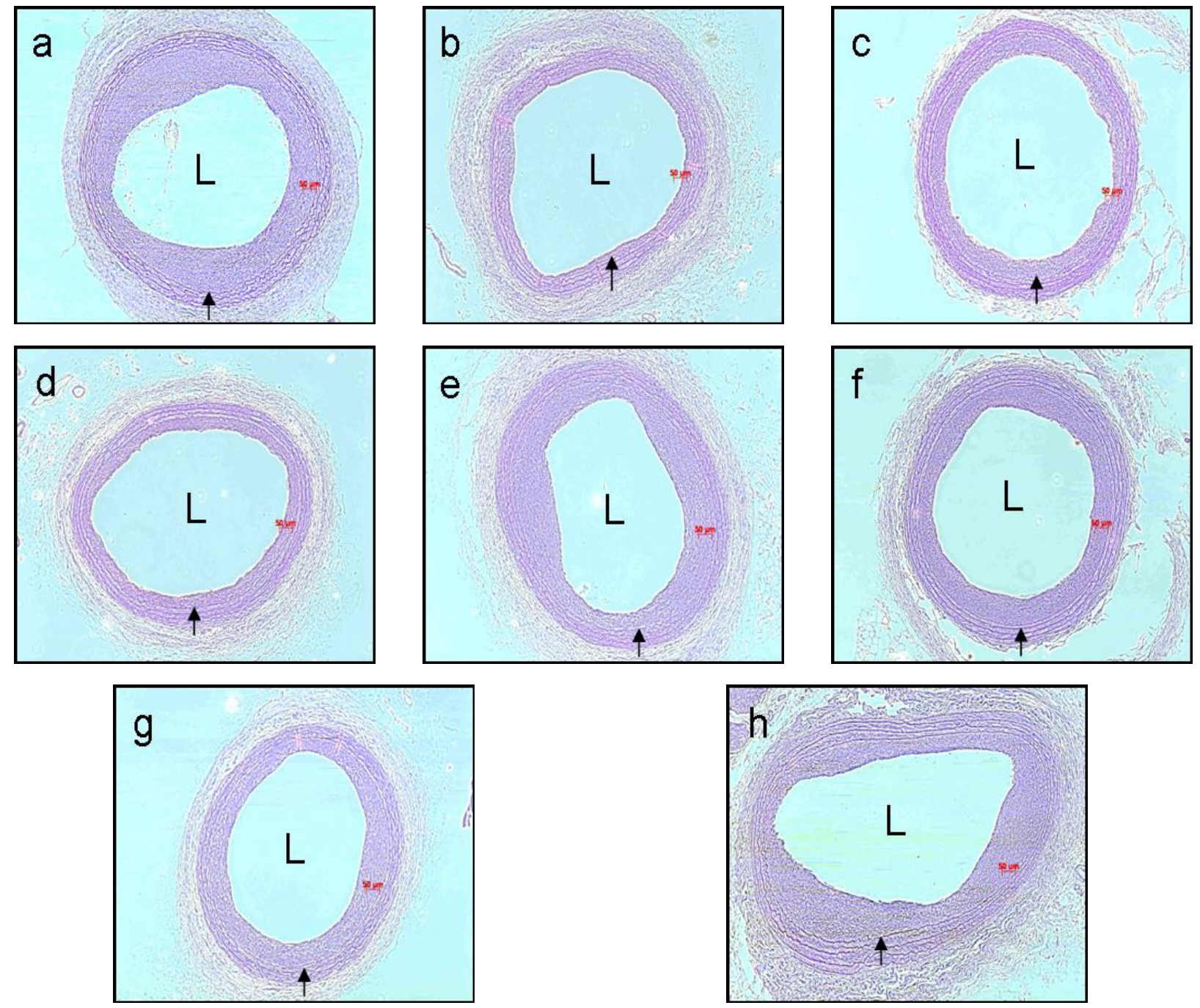

Fig. 1. Histological analysis of the effect of 7TKFs on balloon injured rat arteries. a. control (injured, sample untreated, intimal area : $152 \pm 17 \mathrm{~mm}^{2}$ ); b. SST-treated rat (intimal area : $71 \pm 15 \mathrm{~mm}^{2}$ ); c. BST-treated rat (intimal area : $96 \pm 12 \mathrm{~mm}^{2}$ ); d. KHT-treated rat (intimal area : $92 \pm 13 \mathrm{~mm}^{2}$ ); e. KBH-treated rat (intimal area : $143 \pm 20 \mathrm{~mm}^{2}$ ); f. TST-treated rat (intimal area : $142 \pm 37 \mathrm{~mm}^{2}$ ); g. SSS-treated rat (intimal area : $131 \pm 39 \mathrm{~mm}^{2}$ ); h. CKT-treated rat (intimal area : $144 \pm 20 \mathrm{~mm}^{2}$ ). The selected 7 TKFs were orally administered with same dose $(400 \mathrm{mg} / \mathrm{kg} / \mathrm{day}, \mathrm{n}=8)$ of the each formulation for 4 weeks after denudation. Arrow $=$ internal elastic lamina; $\mathrm{L}=$ luminal; scale bar $=50 \mu \mathrm{m}$.

observed in the uninjured artery (normal). The intimal layer of the uninjured artery only comprised of an endothelial cell layer on the internal elastic lamina (data not shown). Balloon injured carotid artery excised from all groups exhibited loss of endothelium and development of intimal hyperplasia. As shown in the Fig. 2, the mean intimal area of the control (injured, sample untreated) was $152 \pm 17 \mathrm{~mm}^{2}$. The administration of Samhwang-sasim-tang (SST), Banha-sasim-tang (BST) and Kegi-honghwa-tang (KHT) caused inhibition of intimal area $\left(71 \pm 15 \mathrm{~mm}^{2}, 96 \pm 12 \mathrm{~mm}^{2}\right.$ and $92 \pm 13 \mathrm{~mm}^{2}$ respectively). As shown in Fig. 3, the mean intimal area/medial area (I/M) ratio of the control was $1.01 \pm 0.048$ while the administration of SST, BST and KHT caused significant inhibition of $\mathrm{I} / \mathrm{M}$ ratio $(0.56 \pm 0.096,0.78 \pm 0.11$ and $0.71 \pm 0.13$ respectively). Similarly, SST, BST and KHT inhibited the stenosis rate by $78.2 \pm 6.5 \%, 64.5 \pm 5 \%$ and $68.5 \pm 3.2 \%$ respectively. The medial area of 7TKFs treated groups was not significantly different from control. 
Intimal area

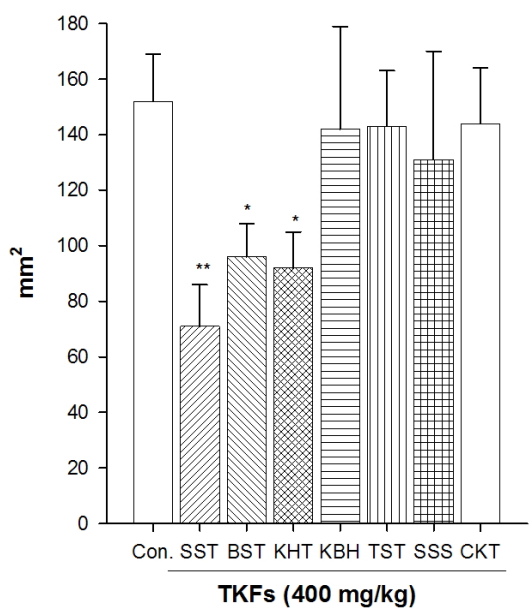

Medial area

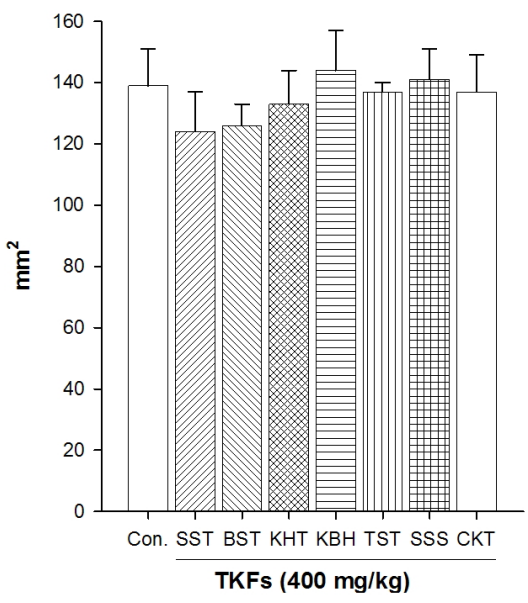

Luminal area

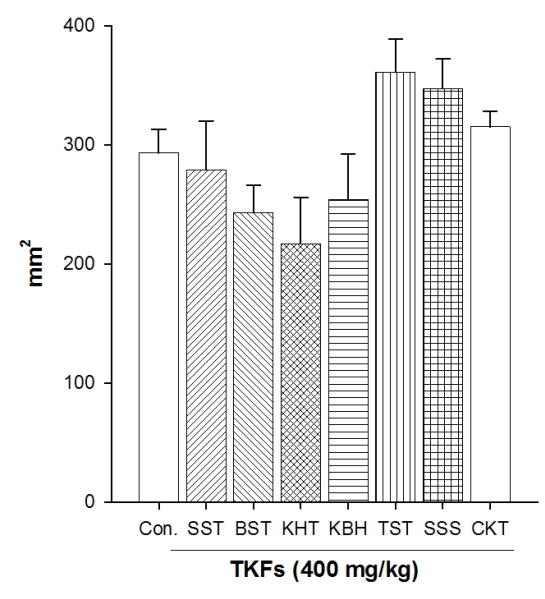

Fig. 2. Effect of 7TKFs on intimal area, medial area and luminal area in rat carotid artery after balloon endothelial denudation. Each data represents mean \pm standard deviation $(\mathrm{n}=8)$. ${ }^{*}, * *$ Significantly different from the control group (injured, sample untreated) at $p<0.05, p<0.01$.

I/M ratio

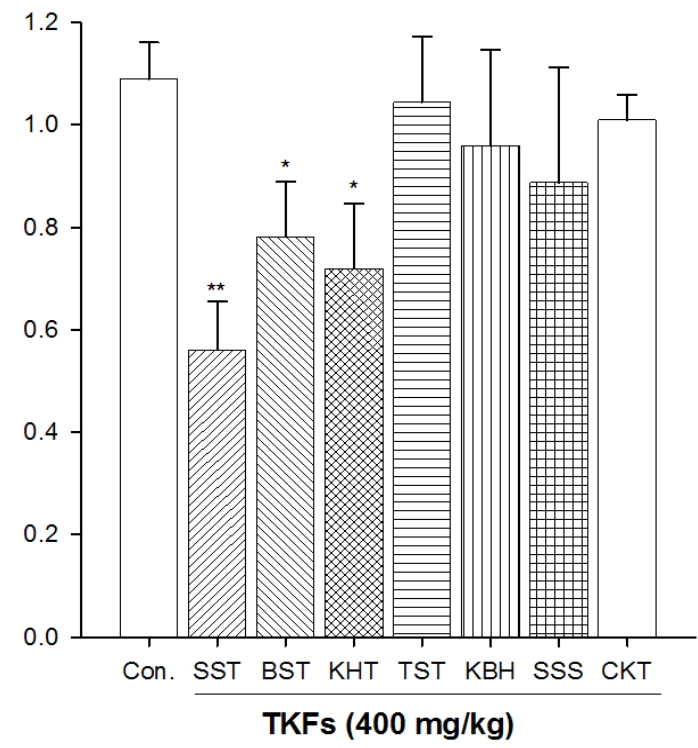

Stenosis rate

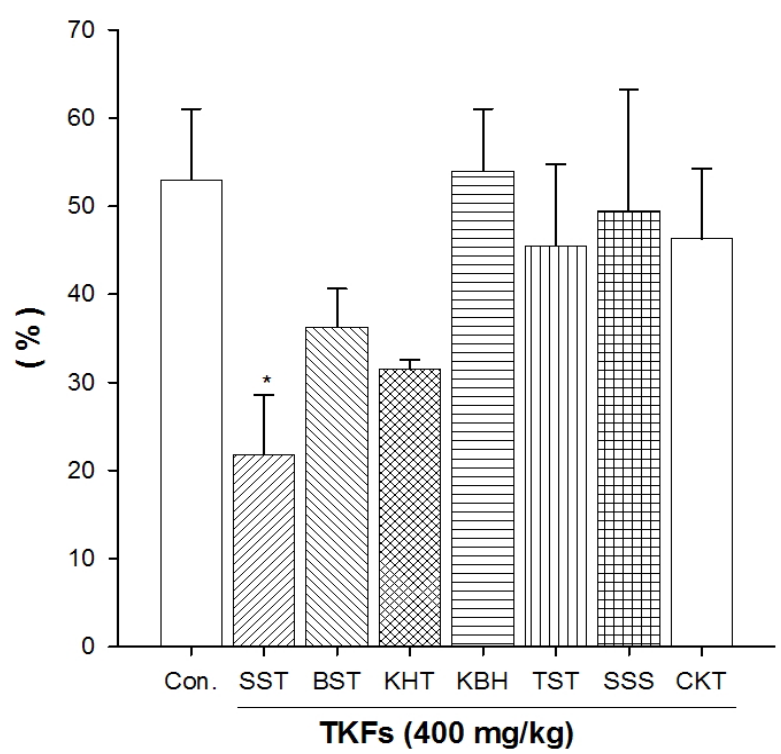

Fig. 3. Effect of 7TKFs on I/M ratio and stenosis rate of rat carotid artery injured by balloon endothelial denudation. Each data represents mean \pm standard deviation $(\mathrm{n}=8)$. *, ** Significantly different from the control group (injured, sample untreated) at $p<$ $0.05, p<0.01 . \mathrm{I} / \mathrm{Mratio}=($ intimal area $) /($ medial area $)$, stenosis ratio $(\%)=($ intimal area $) \times 100 /$ (intimal area + luminal area $)$. The carotid arteries were removed at 4 weeks after denudation and examined.

Since its introduction in 1977 by Andreas Gruntzig, percutaneous transluminal coronary angioplasty (PTCA) has become a popular procedure used to dilate atherosclerotic vessels to alleviate angina pectoris, eventually preventing myocardial infarction, or to revascularize the infarcted myocardium. The major limitation of the long-term success of PTCA is restenosis, a pathological process provoking recurrent arterial narrowing at the site of the intervention 
(Topol et al., 1993). The details of the mechanism of action of 7TKFs remain to be elucidated, but the findings of this study are pharmacological evidence to consider SST, BST and KHT as the therapeutic option for the prevention of restenosis.

\section{Effect of 7TKFs on proliferation of HASMC}

Fig. 4 shows the effect of 7TKFs on the proliferation of human smooth muscle cells (HASMC). SST and BST at a concentration of $100 \mathrm{mg} / \mathrm{ml}$ possessed the proliferation rate $83 \pm 0.8 \%$ and $83 \pm 2 \%$ of control value $(10 \%$ FBS without 7TKFs) respectively. Similarly, SST at concentration of 1000 $\mu \mathrm{g} / \mathrm{ml}$ possessed cytotoxic effect as compared to normal
(0.4\% FBS without 7TKFs) while BST and KHT possessed the proliferation rate $58 \pm 2 \%$ and $70 \pm 1.5 \%$ of control.

Since smooth muscle cell proliferation are the leading factors in the progression of intimal hyperplasia, a key event of atherosclerosis and restenosis after percutaneous coronary intervention (PCI) (Inoue and Node, 2009), inhibition of vascular smooth muscle cells (VSMC) proliferation represents an important therapeutic strategy for treatment of atherosclerosis and restenosis.

\section{Effect of 7TKFs on MMP-2 expression in HASMC}

Fig. 5 depicts the effect of 7TKFs on enzymatic action of

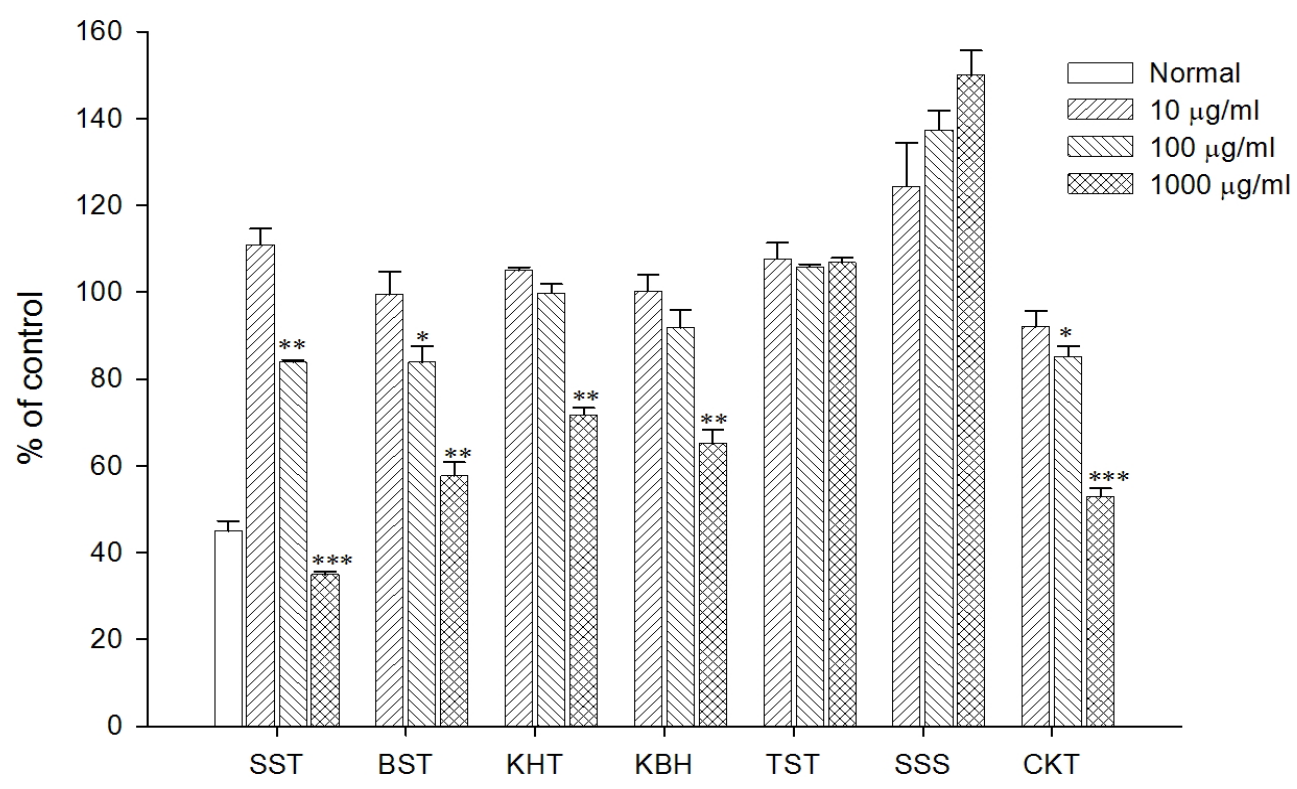

Fig. 4. Effect of 7TKFs on proliferation of HASMC. Results represent average of 3 independent experiments performed in triplicate. $*, * *, * * *$ Significantly different from the control group (sample untreated) at $p<0.05, p<0.01, p<0.001$. Each group contained $10 \%$ fetal bovine serum excepting normal group. Values are means \pm standard deviation.

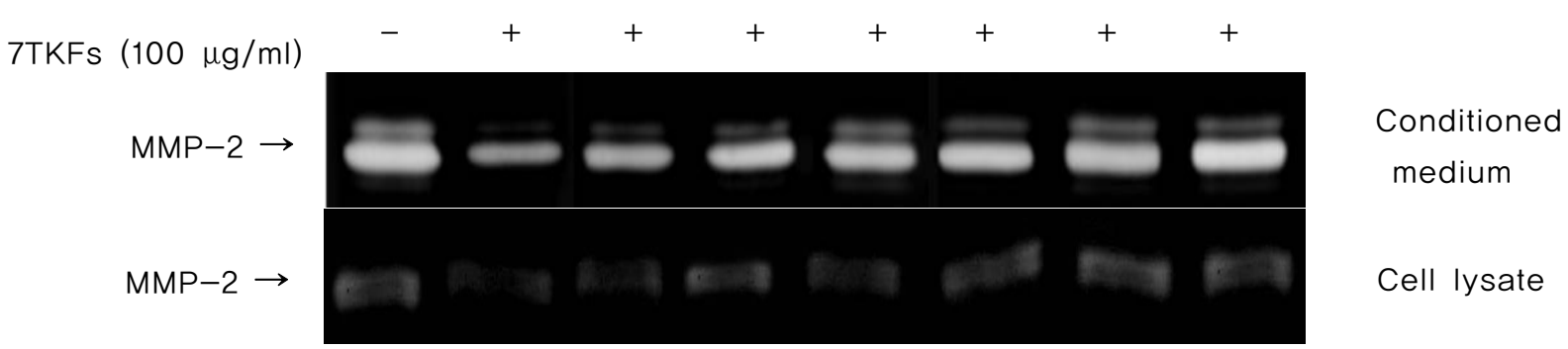

Fig. 5. Effect of 7TKFs on enzymatic action of MMP-2 in HASMC. Lane 1; control, Lane 2; SST, Lane 3; BST, Lane 4; KHT, Lane 5; KBH, Lane 6; TST, Lane 7; SSS, Lane 8; CKT. Densitometric analyses of the zymograms quantified using the NIH Image 1.34 program are presented as the relative ratio of secretion of MMP-2 by addition of 7 TKFs. These studies show the secretion of MMP-2 by HASMCs but not the secretion of MMP-9. 
matrix metalloproteinase-2 (MMP-2) in HASMC. To examine the inhibitory effect of 7TKFs on MMP-2 enzymatic action, the cells were treated with $100 \mathrm{mg} / \mathrm{ml}$ of $7 \mathrm{TKFs}$ for $24 \mathrm{~h}$. Then, the conditioned media was subjected to gelatin zymography. Among 7TKFs, SST, BST and KHT significantly inhibited enzymatic action of MMP-2 in both extracellular and intracellular levels.

A number of studies have shown that among MMPs, MMP-9 is expressed in injured arterial walls only in early phase after injury that MMP-2 is expressed constitutively in a latent form in the arterial wall and over expressed in an activated form during the period from 5 to 14 days after injury, and that MMP-2 deficiency significantly reduced neointimal hyperplasia (Bendeck et al., 1994; Kuzuya and Iguchi, 2003). In our study, SST, BST and KHT significantly inhibited MMP-2 expression in HASMC in both extracellular and intracellular levels.

\section{Literature Cited}

Anitha, J. and G. Tuszynski. 2001. The role of matrix metalloproteinases in tumor angiogenesis and tumor metastasis. Pathol. Oncol. Res. 7:14-23.

Bavry, A.A., D.J. Kumbhani, T.J. Helton and D.L. Bhatt. 2005. Risk of thrombosis with the use of sirolimus-eluting stents for percutaneous coronary intervention (from registry and clinical trial data). Am. J. Cardiol. 95:1469-1472.

Bendeck, M.P., N. Zempo, A.W. Clowes, R.E. Galardy and M.A. Reidy. 1994. Smooth muscle cells migration and matrix metalloproteinase expression after arterial injury in the rat. Circ. Res. 75:539-545.

Clowes, A.W., M.A. Reidy and M.M. Clowes. 1983. Kinetics of cellular proliferation after arterial injury, I: smooth muscle growth in the absence of endothelium. Lab. Invest. 49:327-333.

Dobesh, P.P., Z.A. Stacy, A.J. Ansara and J.M. Enders. 2004. Drug-eluting stents: a mechanical and pharmacological approach to coronary artery disease. Pharmacotherapy 24:15541577.

Fingerle, J., R. Johnson, A.W. Clowes, M.W. Majesky and M.A. Reidy. 1989. Role of platelets in smooth muscle cell proliferation and migration after vascular injury in rat carotid artery. Proc. Natl. Acad. Sci. USA. 86:8412-8416.
Glass, C.K. and J.L. Witztum. 2001. Atherosclerosis. The road ahead. Cell 104:503-516.

Hideaki, N.J. and W.J. Frederick. 1999. Matrix metalloproteinases. J. Biol. Chem. 274:21491-21494.

Inoue, T. and K. Node. 2009. Molecular basis of restenosis and novel issues of drug eluting stents. Circ. J. 73:615-621.

Jackson, C.L. and S.M. Schwartz. 1992. Pharmacology of smooth muscle cell replication. Hypertension 20:713-736.

Kim, D.W., H.J. Chung, K. Nose, I. Maruyama and T. Tani. 2002. Preventive effects of a traditional Chinese formulation, Chaihu-jia-Longgu-Muli-tang, on intimal thickening of carotid artery injured by balloon endothelial denudation in rats. J. pharm. pharmacol. 54:571-575.

Kuzuya, M. and A. Iguchi. 2003. Role of matrix metalloproteinases in vascular remodeling. J. Atheroscler. Thromb. 10:275-282.

Lafont, A. and D. Faxon. 1998. Who animy dal models of post-angioplasty restenosis sometimes poorly predict the outcome of clinical trials? Cardiovasc. Res. 39:50-59.

Linder, V. and M.A. Reidy. 1991. Proliferation of smooth muscle cells after vascular injury is inhibited by an antibody against fibroblast growth factor. Proc. Natl. Acad. Sci. USA. 88:37393743.

Matrisian, L.M. 1990. Metalloproteinases and their inhibitors in matrix remodeling. Trends. Genet. 6:121-125.

Newby, A.C. and A.B. Zaltsman. 2000. Molecular mechanisms in intimal hyperplasia. J. Pathol. 190:300-309.

Nilsen, D.W., T. Melberg, A.I. Larsen, S. Barvik and V. Bonarjee. 2006. Late complications following the deployment of drug-eluting stents. Int. J. Cardiol. 109:398-401.

Pauly, R.R., A. Passaniti, C. Bilato, R. Monticone, L. Cheng, N. Papadopoulos, Y.A. Gluzband, L. Smith, C. Weinstein and E.G. Lakatta. 1994. Migration of cultured vascular smooth muscle cells through a basement membrane barrier requires type IV collagenase activity and is inhibited by cellular differentiation. Circ. Res. 75:41-54.

Sasaguri, Y., N. Murahashi, K. Sugama, S. Kato, K. Hiraoka, T. Satoh, H. Isomoto and M. Morimatsu. 1994. Developmentrelated changes in matrix metalloproteinase expression in human aortic smooth muscle cells. Lab. Invest. 71:261-269.

Thyberg, J. 1998. Phenotypic modulation of smooth muscle cells during formation of neointimal thickenings following vascular injury. Histol. Histopathol. 13:871-891.

Topol, E.J., F. Leya, C.A. Pinkerton, P.L. Whitlow, B. Hofling, C.A. Simonton, R.R. Masden, P.W. Serruys, M.B. Leon, D.O. Williams, et al. 1993. Comparison of directional atherectomy 
with coronary angioplasty in patients with coronary artery disease. N. Engl. J. Med. 329:222-227.

Woessner, J.F. 1991. Matrix metalloproteinases and their inhibitors in connective tissue remodeling. FASEB J. 5:21452154 .
Yoon, J.J., Y.J. Lee, J.S. Kim, D.G. Kang and H.S. Lee. 2010. Betulinic acid inhibits high glucose-induced vascular smooth muscle cells proliferation and migration. J. Cell. Biochem. 111:1501-1511.

(Received 23 October 2013 ; Revised 28 November 2013 ; Accepted 2 December 2013) 